\title{
As ENCRUZILHADAS DA DEMOCRACIA
}

\author{
RANCIÈRE, Jacques. \\ O ódio à democracia. \\ Tradução de Mariana Echalar. \\ São Paulo: Boitempo, 2014. 125 p. \\ POR \\ SidNei Ferreira de VARES ${ }^{1}$
}

Jacques Rancière nasceu em Argel, em 1940. Nos anos de 1960 formou-se na renomada École Normale Supérieure, em Paris. Em 1969, começou a lecionar no Centre Universitaire Expérimental de Vincennes, que poucos anos depois se tornaria a Universidade de Paris VIII. Ali aposentou-se em 2000. Trabalhou com Alain Badiou, Etienne Balibar e Pierre Macherey, todos eles discípulos do filósofo marxista Louis Althusser. O próprio Rancière seguiu Althusser até meados de 1968, quando, mediante o desenrolar dos levantes de maio, distancia-se de seu mentor, sobretudo em relação ao papel das revoltas populares. Grande parte de sua produção inicial esteve voltada ao estudo e à recuperação histórica da experiência das classes trabalhadoras francesas no decorrer do século XIX que tinha sido negligenciada pela historiografia oficial. Inclusive, sua tese de doutorado, La formation de lapenséeouvrière em France: leprolétaire et sondouble, defendida em 1980, é uma clara amostra disto. Mais recentemente, passou a dedicar-

Professor de História, Filosofia e Pedagogia do UNIFAI e de Pedagogia do UNISANTANNA. vares@usp.br 
se às interfaces entre estética e política e, também, ao tema da democracia na contemporaneidade, em especial à relação entre igualdade e liberdade, contrapondo-se, assim, a visão historicamente consolidada de filósofos como Platão e Aristóteles, bem como a de pensadores contemporâneos como Gilles Deleuze e a outros menos conhecidos como Joseph Jacototy e Gabriel Gauny.

Seu mais recente trabalho $O$ ódio à democracia, recentemente publicado no Brasil pela Editora Boitempo, divide-se em quatro seções, precedidas por uma breve introdução. Trate-se de um ensaio cuja intenção é analisar os rumos da democracia contemporânea. Apesar do tom filosófico, o autor recorre à história para captar as transformações e as continuidades que encerram a democracia clássica, a moderna e a contemporânea.

Logo na "Introdução", Rancière chama a atenção sobre como a democracia contemporânea é encarada por uma parcela considerável de jornalistas, filósofos, sociólogos, cientistas políticos e psicanalistas: "o reino dos desejos ilimitados dos indivíduos da sociedade de massa moderna" (p. 8). Para o autor, essa "acusação singular" à democracia não constitui uma novidade. Desde a Grécia Antiga, pelo menos, é possível avistar insultos deste tipo por aqueles que, em defesa da ordem legítima, sentiam-se afetados com o avanço do "inominável governo da multidão". Aliás, a expressão "democracia" comporta um tom bastante depreciativo, "sinônimo de abominação para todos os que acreditavam que o poder cabia de direito aos que a ele eram destinados por nascimento ou eleitos por suas competências" (p. 8). A violência decorrente desse ódio, passados tantos séculos, ainda se faz presente. A história, em contrapartida, também se encarregou de produzir formas de crítica à democracia. Duas delas merecem a atenção do autor, a saber, aquela representada por legisladores aristocratas e doutos, que viram na democracia um fato incontornável, como no caso da redação da constituição americana, que se baseou na tentativa de preservar a meritocracia e a ordem social estabelecida; e a de seu antípoda, isto é, daqueles que lutam por uma democracia "real", em que liberdade e igualdade estão longe de serem meros epifenômenos do Estado burguês. Destarte, segundo 
Rancière, o novo ódio à democracia se traveste na defesa de um poder estatal aparentemente democrático e "real", conquanto as leis e as instituições que dele decorrem subvertam-se em instrumentos da dominação burguesa. Desde Montesquieu, Madison ou Tocqueville, entretanto, é o povo em seu conjunto, e não as instituições ditas "democráticas", o alvo das críticas. Assim, o novo sentimento antidemocrático procura evitar que o "governo democrático" se deixe corromper pela "sociedade democrática", cujo grande mote é a luta pela igualdade e pelo respeito a todas as diferenças. Em outros termos, só existiria uma única democracia "boa", a saber, "a que reprime a catástrofe da civilização democrática" (p. 11). É este escândalo contido na palavra democracia que Rancière procura denunciar.

Na primeira seção, intitulada "Da democracia vitoriosa à democracia criminosa", Rancière destaca alguns fatos recentes de nossa história, como as eleições no Iraque, as manifestações em Beirute contra a Síria e as incursões militares dos Estados Unidos em países tradicionalmente autoritários, com vistas a demonstrar que por trás do elogio à democracia, escondem-se alguns dilemas importantes. Segundo o autor, aqueles que defendem que a democracia deve ser levada a qualquer custo (inclusive através da força) a povos não-democráticos, sob o argumento de que os benefícios de um Estado constitucional, eleições e imprensa livres constituem uma espécie de marco civilizatório, paradoxalmente rejeitam a bagunça e a desordem típicas de um regime democrático "real". Aliás, para esses paladinos da democracia, o real é ideal, ou seja, a noção de um governo do povo por ele mesmo não passa de mera utopia. Destarte, dois são os inimigos da democracia: (a) o inimigo externo, composto por governos arbitrários, despóticos, totalitários ou ditatoriais; (b) e o inimigo interno, por isso íntimo, representado por governos pseudo-democráticos, que falam abertamente em uma "boa" democracia, isto é, em um sistema político que seja capaz de controlar os excessos, seja na forma de uma intensa atividade coletiva seja na forma de individualismo exacerbado, à medida que ambas as formas expressam um contexto de "crise", cujos efeitos são perniciosos à 
consolidação da experiência democrática burguesa. Mas, o que seria uma "boa" democracia na ótica burguesa? Rancière responde: "A boa democracia deveria ser então uma forma de governo e de vida social capaz de controlar o duplo excesso de atividade coletiva ou de retração individual inerente à vida democrática", já que qualquer excesso, "significa a ruína do governo democrático e, portanto, deve ser reprimido por ele" (p.17). Ancorado em um trabalho de Jean-Claude Milner, "As tendências criminosas da Europa democrática", Rancière demonstra como essa visão acerca de uma "boa" democracia sorveu, sobretudo no decorrer da segunda metade do século XX, certos traços típicos do totalitarismo, transformando as diferenças e mesmo as tensões inerentes ao jogo democrático num risco à sociedade democrática burguesa - a "boa".

Já na segunda seção "Política ou o pastor perdido", Rancière, adotando a posição do exegeta, lança o seu olhar sobre as origens da divisão entre a "boa" e a "má" democracia. Argumenta que o crime da democracia está atrelado ao crime político, isto é, ao surgimento da política enquanto prática desvinculada da religião ou do "pastor divino" que conduzia as massas. Nesse sentido, a democracia não nasceu da descrença moderna que acometeu o século das luzes, mas entre os antigos gregos, que romperam o vinculo com os que falavam em nome da divindade. Mas, segundo Rancière, essa constatação deve ser vista com algum cuidado. Isto porque, mesmo entre os antigos, alguns pensadores procuraram minimizar essa ruptura. $\mathrm{O}$ caso mais expressivo é, sem dúvida, o de Platão. Não que o filósofo ateniense negue por completo a separação entre política e religião, mas porque evoque em textos como "Político" ou mesmo em sua "República" a presença de governantes superiores aos guerreiros e aos artesãos, capazes de garantir a ordem social. Não por acaso, Platão, que dispensa a figura do governantepastor, adota, entretanto, a figura do governante-médico ao falar de política. Na prática, porém, ambos se igualam, não só porque se opõem à figura do tirano, mas porque dispõe da virtude de governar em proveito dos que deles dependem, desde que estes não participem diretamente do governo. 
A crítica de Platão à democracia (entendida em seu sentido original, ou seja, como "poder do povo") é justamente essa: trata-se de um estilo de vida e não de um regime político autêntico, caracterizado pelos desejos desmedidos dos indivíduos que, igualados, põe em risco qualquer laivo de organização social.

Destarte, ainda que Platão contraponha o reino da política ao da tirania, não deixa de legitimar a figura do condutor político, do especialista, que, exatamente por sua capacidade de gestão, evite as desordens típicas da "desmedida democrática", já que esta "inverte a relação entre governante e governado", descartando as distinções sociais responsáveis por garantir "a ordem da sociedade e a ordem do governo" (p. 53). Mas Rancière vai ainda mais longe: afirma que Platão, ao admitir a existência de governantes e governados em todas as cidades, constitui o primeiro pensador ocidental a denunciar o "escândalo" democrático, "um escândalo para as pessoas de bem, que não podem admitir que seu nascimento, sua ancianidade ou ciência tenha que se inclinar diante da lei da sorte" (p. 56). Assim sendo, o filósofo ateniense "quer suprimir a desordem democrática para fundar a verdadeira política, mas só pode fazê-lo com base nessa própria desordem, que cortou o vínculo entre os chefes das tribos da cidade e os daimones ${ }^{2 *}$ que serviam a Cronos" (p. 62). E assim prossegue o autor: "A democracia não é um tipo de constituição nem uma forma de sociedade. O poder do povo não é o da população reunida, de sua maioria ou das classes laboriosas. É simplesmente o poder próprio daqueles que não têm mais título para governar do que para ser governados" (p. 63). Mas eis que há, aqui, um paradoxo. Se o poder dos que governam é um poder político, não natural; e se a submissão dos governados é igualmente política, então, o poder dos melhores (seja o dos mais ricos, dos mais velhos ou dos mais sábios) só pode se legitimar pelo poder dos iguais. Por isso Platão faz do governante um homem sem propriedade, que apenas um feliz acaso chamou ao governo. Em suma,

2 *Trata-se de uma expressão típica da mitologia grega que se refere a uma raça superior enviada pelos deuses para governar os homens. 
conclui Rancière sobre as queixas usuais sobre a democracia ingovernável: “a democracia não é nem uma sociedade a governar nem um governo da sociedade, mas é propriamente esse ingovernável sobre o qual todo governo deve, em última instância, descobrir-se fundamentado" (p. 66).

Na terceira seção, "Democracia, república, representação", Rancière procura desvelar os paradoxos que envolvem a noção de democracia representativa. Ao ressaltar o esforço circular de Hobbes que, ao descrever a natureza a partir da sociedade, termina por assumir a inutilidade em procurar a origem da comunidade política em uma virtude inata de sociabilidade, Rancière pretende demonstrar que uma filosofia destinada a procurar o princípio do bom governo ou das razões pelas quais os homens fundam governos é impossível. Isto porque a "sociedade democrática" não designa nem uma forma de sociedade nem uma forma de governo. Ela é apenas uma abstração, já que, tanto no passado quanto no presente, é organizada pelo jogo das oligarquias. De modo geral, afirma o autor, reduz-se a discussão através da oposição entre democracia direta e democracia representativa, sendo a primeira uma experiência adequada a sociedades demograficamente menores e a segunda a sociedades maiores. Mas é possível levar a sério a noção de representação? Bem, segundo Rancière, essa relação entre crescimento populacional e democracia representativa é uma grande falácia, pois, aqueles que supostamente "representam" a maioria são, na verdade, os que têm título para exercer o poder e se ocupar de negócios comuns. Em outros termos, talvez a denominação proposta por Raymond Aron, "regime constitucional pluralista" seja mais precisa do que "democracia representativa", pois, ao fim e ao cabo, este tipo de sociedade está fundamentado no privilégio das elites, que exerce o poder reconhecidamente do povo, para que este não arruíne o princípio do governo. Ora, desta feita, o sentido mais original da expressão "democracia” torna-se obsoleto. Aliás, essa é uma das artimanhas da ideologia republicana, que, embora faça apologia à inclusão de eleitores e elegíveis no processo político, restringe, a partir da dualidade do homem público e do cidadão comum, o limite da esfera pública, empurrando para 
o âmbito da vida privada as intervenções dos atores não estatais. Como resultado desta separação, tão difundida nas repúblicas modernas, impõese a dominação dos que dispõem do título de homens públicos nessas duas esferas. Em outras palavras, por trás do atrativo discurso do individualismo democrático, esconde-se uma lógica de dominação similar àquela imposta, por exemplo, pelos bens-nascidos na Grécia Antiga, pela nobreza na Idade Média ou pela burguesia na Idade Moderna.

Na quarta e última seção, "As razões de um ódio", Rancière encara os motivos que fomentam o ódio ao exercício democrático autêntico. O autor retoma, assim, o problema inicial do texto. Vivemos em sociedades e Estados que se denominam "democráticos", quando comparados com sociedades governadas sem lei ou por leis religiosas. Entretanto, no interior dessas mesmas "democracias" há sempre uma intelligentsia dominante que, além de não abrir mão de seus privilégios, tão pouco esconde o que acredita ser o leimotiv das desgraças humanas: a democracia. Aparentemente, tratase, pois, de um paradoxo. Mas, considerando que essas democracias não passam, na verdade, de oligarquias travestidas, vê-se claramente que o motivo dessa acusação repousa em preconceitos atávicos, cujas origens são bem remotas. Grosso modo, viver em democracia não significa viver em uma forma de Estado, isto porque ela está "aquém" e "além" de quaisquer formas. Aquém, na medida em que tem como fundamento a igualdade, esquecida pelos Estados Oligárquicos. Além, na medida em que estimula a atividade pública, impensável em um Estado monopolizador. Mesmo que consideremos algumas regras mínimas para chamarmos uma sociedade de "democrática", tal como sistema representativo, mandatos eleitorais, monopólio dos representantes do povo sobre a elaboração das leis etc., verificaremos, conforme o autor, que, na prática, essas regras só são capazes de garantir o governo dos que amam o poder pelo poder. Desse ponto de vista, não vivemos em democracias, mas sim em Estados Oligárquicos, cujo poder é limitado pelo duplo reconhecimento da soberania popular e das individualidades, mas que em seu modus operandi dá “à minoria mais forte 
o poder de governar sem distúrbios e criar uma maioria e uma oposição que estão de acordo com as políticas a ser praticadas" (p.97). Por trás dessa manobra está, sem dúvida, a grande aspiração das oligarquias, a saber, "governar sem o povo, isto é, sem divisão do povo; governar sem política" (p. 102). Promovendo uma aliança entre riqueza e ciência, as elites dirigentes tentam impedir que o povo se divida e se multiplique. Em nome do consenso dominante, essas elites geram, propositadamente, uma contradição entre a legitimidade popular e a científica, encampando para si a autoridade desta última, de tal modo que toda a oposição ao discurso científico seja tomada como um ato de ignorância.

Com efeito, a ideia-força deste consenso é que o movimento econômico mundial e o avanço científico atestam uma necessidade histórica a que devemos nos adaptar e que somente os representantes de interesses arcaicos e ideologias ultrapassadas podem negar. O ódio à democracia, portanto, eclode na mesma medida em que as pressões populares se fortalecem e delimitam o raio de ação desses oligarcas, fazendo-os ceder neste ou naquele ponto.

$\mathrm{O}$ ensaio de Jacques Rancière não é para principiantes. $\mathrm{O}$ autor executa inúmeras incursões no campo da história e da filosofia política, sem se preocupar com o didatismo. Mas apesar das dificuldades impostas pela forma textual do referido ensaio, facilmente se extrai as ideias centrais. Nesse sentido, há uma perceptível preocupação do autor em demonstrar que a palavra "democracia", embora agregue inúmeras possibilidades, que vão desde eleições diretas até a igualdade entre os cidadãos-republicanos, em nada se aproxima de seu sentido mais original do "poder do povo". Historicamente, o que se efetivou no ocidente foram oligarquias revestidas de um discurso democrático, mas não de uma prática democrática. Isto porque uma democracia autêntica pressupõe conflitos, divisões e tensões. Ora, é 
exatamente neste ponto que a ameaça democrática se faz presente: ela põe em risco a estabilidade, a unidade e a ordem social, à medida que amplia os limites da esfera pública. E isso, alerta o filósofo francês, é tudo o que as elites não desejam. Eis a farsa dos governos "democráticos" contemporâneos. A capacidade de análise de Rancière constitui o seu grande mérito. A sugestão de que, a despeito da proliferação de governos eleitos, da expansão dos direitos humanos e do surgimento de novas tecnologias, há uma continuidade histórica acerca da prática autoritária, não deixa de ser perspicaz. É este, certamente, o ponto forte do livro: identificar os entraves que impedem a democratização da esfera pública e o avanço do exercício da política em seu sentido estrito. Em suma, trata-se de um ensaio imprescindível para os estudiosos da área política, não por incrementar novas ideias à discussão sobre a democracia, mas por apresentar, de modo organizado e profundo, os paradoxos que corroboram para a sua inanição. A nota baixa, a meu ver, fica por conta do olhar unilateral do autor, que se dirige única e exclusivamente às elites liberais. Com isso, fica a impressão de que o maior empecilho à expansão das liberdades democrática centra-se nos interesses indomáveis de um grupo de privilegiados capitalistas. Penso que a discussão em torno dos entraves que emperram a efetivação de uma democracia autêntica poderia ser expandida para além do espectro político liberal, englobando, também, o espectro político socialista, em especial a nova esquerda que se configurou com o fim da União Soviética e com a queda do Muro de Berlim. Não seria demais refletir sobre as possibilidades e as dificuldades inerentes à implantação de um governo de esquerda democrático. 